\title{
Obituaries
}

Obituaries should be submitted by email to Kate Maynard at k.maynard@nature.com.

All submitted obituaries should be 400 words maximum in length (apart from obituaries for past presidents of the BDA where the length should be $700-800$ words) Content of the obituary is down to the individual author, and the approval of the family should be given for the obituary prior

to submission to the $B D J$.

\section{IAN EARNEST BARNES}

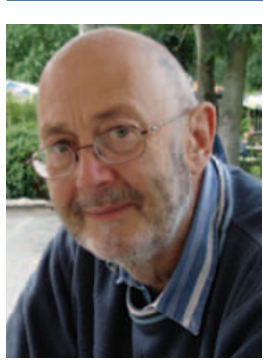

Professor Ian Barnes died recently after a short illness. He was 68.

Born and brought up in Winchmore Hill, North London, he graduated from UCH in 1961, and after three years of remote and scarily ill-equipped practice in the Falkland Islands, returned to obtain his FDSRCS and a $\mathrm{PhD}$ under the guidance of Alan Boyde.

He developed and never lost a selfconfident mastery of surgery, but soon opted for a lectureship in 'Dental Surgery', a far cry from contemporary specialisation, which allowed the Dean to direct his small team in such endeavours as were required across the curriculum. As a clinical teacher he was friendly but meticulous, always direct and analytical in his feedback, unstinting with his time and motivated by what would protect and benefit students and their patients in the future. An intensely practical man, and an accomplished researcher, he nevertheless retained a healthy cynicism of much dental research, managing his appreciative patients with a wisdom and kindness guided at least as much by astute clinical observations as by nebulous statistics. It was in surgical endodontics that he developed his greatest profile, authoring a benchmark colour atlas, serving the British Endodontic Society as President, and patenting the 'Barnes' apicectomy amalgam gun.

In 1983, he took a Chair at Newcastle, building a strong team of restorative lecturers whom he nurtured and promoted with characteristic modesty, kindness and legendary wit. In the mid-1990s, he responded to new challenges, first in Hong Kong and then in Malaysia.

In 2002, he returned to Northumberland, drove a mini-bus for the local accessibility service and became an adult literacy tutor. His voice became familiar to the visually impaired as a regular reader for the Talking Newspaper Service. His firm belief that true reward comes from what you put into life was reflected not just in his professional career but in the kindness and generosity of his many friends, especially in the weeks leading up to his death.

Ian is survived by his wife Jan, daughters Catherine and Judith, granddaughter Tilly, son-in-law, Paul and dog, Olive.

$\mathrm{CB} / \mathrm{DS} / \mathrm{RW} / \mathrm{JW}$

\section{JOHN DAVID HOOPER}

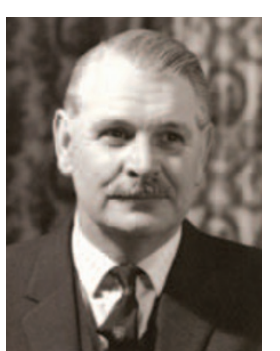

John Hooper was the first Consultant Orthodontist in England to be appointed to a District General Hospital following the inception of the National Health Service. His example helped to determine the pattern for the future delivery of orthodontic services in this country. He died at the age of 92 on 12 December 2008.

John David Hooper was born on 7 April 1916 and was educated at Ardingly College. He qualified in dentistry at the Royal Dental Hospital and then joined the staff in the orthodontic department. Following the outbreak of the Second World War, he was captured in Belgium and spent five years as a prisoner of war.
Following liberation he married Sybil (née Morrison), a farmer's daughter from East Lothian; they celebrated their diamond wedding anniversary in 2005.

John Hooper was appointed in 1950 at the Royal Victoria Hospital in Bournemouth. Despite a legendary work rate it quickly became apparent that the only way to cope with the demand was to utilise the services of interested local general dental practitioners. He provided them with training courses, diagnosis and treatment planning and continuing support which became a model that was soon followed throughout the country.

He was President of the British Society for the Study of Orthodontics in 1967 and one of the founding members of the Consultant Orthodontists Group, becoming chairman in 1970. He also held the important post of advisor to the Dental Estimates Board which regulated the orthodontic treatment carried out as part of the General Dental Services.

In addition to his professional achievements John was a family man and proud of his children, grandchildren and great grandchildren. He was also a keen sailor and great rugby fan. Both he and Sybil were the most hospitable of hosts and enjoyed the company of their wide circle of friends. Sybil predeceased him in November 2007 and he is survived by his son David, daughter Sheila and their six children.

John ran an efficient, productive but happy department and was completely committed to the ethos of the NHS. He was an excellent clinician and an enthusiastic teacher providing a role model for those of us that had the privilege of working with him.

$\mathrm{SJ} / \mathrm{DH} / \mathrm{RB} / \mathrm{IH} / \mathrm{JH}$ 